\title{
Research Article \\ EFFICACY OF MEDICINAL PLANT EXTRACTS AGAINST COLLAR ROT OF TOMATO CAUSED BY Sclerotium rolfsii (Sacc.)
}

\author{
MAHATO A. ${ }^{*}$ BISWAS M.K. AND PATRA S. \\ Department of Plant Protection, Palli-Siksha Bhavana, Visva-Bharati, Sriniketan, West Bengal, 731236, India \\ *Corresponding Author: Email - asishmahato1989@gmail.com
}

\section{Received: May 15, 2018; Revised: May 26, 2018; Accepted: May 27, 2018; Published: May 30, 2018}

\begin{abstract}
Eight medicinal plant extracts viz. Andrographis paniculata, Zingiber officinale, Azadirachta indica, Allium sativum, Curcuma longa, Catharanthus roseus, Allium cepa and Ocimum sanctum were evaluated against $S$. rolfsiil by following poisoned food technique at 5,10 and 20 per cent concentration in vitro and the effective concentration were also evaluated against collar rot in vivo. Among of them Allium sativum was showed maximum inhibition of $35.31 \%, 68.50 \%$ and $84.89 \%$ of mycelia growth at 5,10 , and 20 percent concentration respectively followed by Azadirachta indica $(31.67 \%, 65.61 \%$ and $80.86 \%)$. The least effective phytoextract was Ocimum sanctum and exhibited $10.67 \%, 30.69 \%$ and $53.47 \%$ inhibition of mycelial growth at 5, 10, and 20 percent concentration respectively. Where as in vivo experiments with $20 \%$ concentration, Azadirachta indica showed best effectiveness against collar rot disease by reducing $64.69 \%$ and $67.26 \%$ disease incidence respectively followed by Allium sativum (60.34\% and $62.65 \%$ ) and least reduction of disease incidence $(29.38 \%$ and $25.30 \%$ ) respectively recorded in Ocimum sanctum in two years of experiments.
\end{abstract}

Keywords- Tomato, Collar Rot, Sclerotium rolfsii, Medicinal Plant Extracts, Management

Citation: Mahato A., et al., (2018) Efficacy of Medicinal Plant Extracts Against Collar Rot of Tomato Caused by Sclerotium rolfsii (Sacc.). International Journal of Microbiology Research, ISSN: 0975-5276 \& E-ISSN: 0975-9174, Volume 10, Issue 5, pp.-1224-1227. DOl: http://dx.doi.org/10.9735/0975-5276.10.5.1224-1227

Copyright: Copyright@2018 Mahato A., et al., This is an open-access article distributed under the terms of the Creative Commons Attribution License, which permits unrestricted use, distribution and reproduction in any medium, provided the original author and source are credited.

\section{Introduction}

The collar rot disease, caused by Sclerotium rolfsii, is one of the major production constraints of tomato (Solanum lycopersicon L.) in majority of warm temperate and subtropical regions of the world. The disease is reported to occur in almost all tomato growing areas of India including West Bengal with causing substantial yield losses. The pathogen likes soft tissues and causes rot of tissues adjacent to soil level termed collar zone causing death by disrupting translocation of food from the top to the root zone [1]. The infection leads to the drying of lower leaves and eventually the whole plant dries giving a typical symptom of wilting. Plants of any age may be attacked. Under favorable conditions of the disease may outbreak in epiphytotic forms and can either affects its yield and quality or cause total failure of the crop incurring substantial losses to the economy of the farmer. The pathogen is a facultative saprophyte, soil inhabitant, ubiquitous and omnipathogenic [2] and can maintain continuity of its generation under adverse situation by the formation of sclerotia [3]. Generally, efficient, and effective management of the disease is achieved by using synthetic pesticides which are known to causes many problems to the environment such as water, soil, animals, and food contamination; poisoning of farmers; elimination of non-target organisms; and selection of phytopathogens, pest and weed insensitive to certain active ingredients. The using synthetic pesticides also escalated costs of cultivation. In this context plant extracts might be a good alternative source for controlling soilborne diseases since they comprise a rich source of bioactive substance [4], which possesses protective, curative, and antagonistic activity against many diseases [5-11]. Plants extracts are eco-friendly due to its biodegradable nature [12] which reduces environmental contamination and health hazards [13] as well as the farmers and small industries can easily produce it [14]. These botanical pesticides are affordable by low income farmers and they have the potentiality for use in agriculture, especially with the dramatic increase towards the consumption of organically produced plants and ensure the sound ecology and friendly environment without any pollution. It is there for dire necessity to work extensively to examine the effect of different indigenous medicinal plant extracts with different concentration, in controlling plant disease which are easily available. Hence, the present studies were undertaken to assess the efficacy of some medicinal plant extracts for the management of collar rot of tomato.

\section{Materials and Methods \\ Experimental site}

The laboratory experiments were conducted at the laboratory of the department of Plant Protection, Palli-Siksha Bhavana (Institute of Agriculture), Visva-Bharati, Sriniketan. The field experiments were conducted at the agricultural farm of PalliSiksha Bhavana (Institute of Agriculture), Visva-Bharati, Sriniketan, West Bengal, during the season of 2014-15 and 2015-16.

\section{Collection, isolation and identification of pathogen}

The Sclerotium rolfsii infected tomato plant was collected from Agriculture Farm of Palli Siksha Bhavana, Visva-Bharati, West Bengal. The fungus was isolated from the stems of infected tomato plants by tissue segment method [15] on potato dextrose agar (PDA) medium. The hyphal tip technique [16], was used to pure culture the fungal isolates. The fungus identified based on its mycelia and sclerotial characters [17]. Repeated culture has been done from tip of the single hyphae to obtain pure culture of the identified Sclerotium rolfsii and the pure culture was stored in the PDA slants at $10^{\circ} \mathrm{C}$ for further use.

\section{Preparation of inoculums}

The pathogen, Sclerotium rolfsii was multiplied on wheat grains $(200 \mathrm{~g})$ soaked overnight in water for pot experiment. 
About $100 \mathrm{~g}$ of soaked wheat grains were taken in $500 \mathrm{ml}$ capacity conical flask and tightly plugged with non absorbent cotton. The flasks were then sterilized by autoclaving at $15 \mathrm{Psi}$ with $121^{\circ} \mathrm{C}$ for 20 minutes. After sterilization, the wheat seeds in flasks were inoculated with $5 \mathrm{~mm}$ mycelial disc from 7 days old pure culture of Sclerotium rolfsii at each flasks and flasks were incubated for a 15 days at $27^{\circ} \mathrm{C} \pm 2^{\circ} \mathrm{C}$ for proper mycelial growth.

\section{Collection and preparation of pot experimental soil}

The soil of pot experiments was collected from Agricultural Research Farm of Visva-Bharati which was air dried, grinded and was screened through 10 mesh sieve to large particles and debris. The soil was sterilized with $5 \%$ formaldehyde solution. After sterilization the soil was air-dried on a concrete floor. The sterilized soil was poured into plastic pot $(20 \mathrm{~cm}$ height and $15 \mathrm{~cm}$ diameter) at the rate of $2.5 \mathrm{~kg}$ soil per pot.

\section{Rising of tomato seedlings}

Tomato seeding was grown in germinating tray with sterilized soil. Thirty days old healthy tomato seedlings were transplanted and grown in the plastic pots. The recommended dose of fertilizer was used with timely watering the plants. After proper establishments of seedling (10 days after transplanting) the inoculums were applied.

\section{Screening of medicinal plants extracts \\ Medicinal plants and parts used for experiments}

Efficacy of eight medicinal plants extracts viz., Kalmegh (Andrographis paniculata), Ginger (Zingiber officinale), Neem (Azadirachta indica), Garlic (Allium sativum), Turmeric (Curcuma longa), Periwinkle (Catharanthus roseus), Onion (Allium cepa) and Tulsi (Ocimum sanctum) were tested at 5, 10, 20 percent of concentrations, against $S$. rolfsii and collar rot disease incidence, in vitro and in vivo. The medicinal plants were collected from local areas to evaluate against Sclerotium rolfsii.

Table-1 Details of medicinal plants and parts used for experiments

\begin{tabular}{|l|l|l|l|l|} 
SN & Common Name & $\begin{array}{l}\text { Botanical } \\
\text { Name }\end{array}$ & Family & $\begin{array}{l}\text { Plant } \\
\text { Part } \\
\text { Used }\end{array}$ \\
\hline 1 & Andrographis paniculata & Kalmegh & Acanthaceae & Leaf \\
\hline 2 & Zingiber officinale & Ginger & Zingiberaceae & Cloves \\
\hline 3 & Azadirachta indica & Neem & Meliaceae & Leaf \\
\hline 4 & Allium sativum & Garlic & Amaryllidaceae & Cloves \\
\hline 5 & Curcuma longa & Turmeric & Zingiberaceae & Cloves \\
\hline 6 & Catharanthus roseus & Periwinkle & Apocynaceae & Leaf \\
\hline 7 & Allium cepa & Onion & Amaryllidaceae & Bulb \\
\hline 8 & Ocimum sanctum & Tulsi & Lamiaceae & Leaf \\
\hline
\end{tabular}

\section{Preparation of cold aqueous extract}

Plant parts were first washed with tap water and then with sterilized distilled water and air dried. Weighted plant materials were grind in pestle and mortar using the ratio 1:1 w/v. The materials were homogenized for 5 minutes then filtered through double layered muslin cloth followed by Whatman No. 1 filter paper and filtrates were considered as standard extract $(100 \%)[18,19]$.

\section{In vitro evaluation}

Efficacy of eight medicinal plants extracts were tested at three different concentrations (viz. 5, 10, 20 percent) each by following poisoned food technique in vitro condition [20]. Different concentration of poisoned food medium i.e., 5, 10 and $20 \%$ were prepared by incorporating the standard leaf extracts solution individually into Potato Dextrose Agar (PDA) medium in $250 \mathrm{ml}$ conical flasks at required quantities and PDA was autoclaved. These melted PDA were poured in $90 \mathrm{~mm}$ sterilized Petri plate and PDA without extracts was maintained as control. All plates were replicated three times. Plates were inoculated with $5 \mathrm{~mm}$ mycelium disc of seven days old culture test fungus and incubated at $26 \pm 10 \mathrm{C}$ for seven days. The radial growth of the mycelium was measured after seven days of incubation and percent inhibition of growth was calculated using the bellow cited formula [21].
Percent inhibition $(I)=\frac{C-T}{C} \times 100$

Where,

I= Percent inhibition

$\mathrm{C}=$ Radial growth of test fungus in control plate

$\mathrm{T}=$ Radial growth of test fungus in treated plate

\section{In vivo evaluation}

To evaluate the fungicidal efficacy of selected medicinal plants extracts, at best performed concentration $(20 \%)$ of in vitro experiment, on collar rot disease incidence, pot experiments was carried out in protected condition by artificial soil inoculation methods in two years 2014-15 and 2015-16. In this experiment $100 \mathrm{ml}$ suspension of each extract was prepared. Required concentration was prepared by dissolving plant extract in $100 \mathrm{ml}$ distilled water. One month old healthy seedlings were grown in plastic pots, containing sterilized soil. Total one hundred thirty five numbers of tomato seedlings was grown for nine treatments (including one control) with three replications. Five pots, with single plant per pot were maintained for each replication. After 10 days of transplanting, when seedling got well established, plants were inoculated by mixing $20 \mathrm{~g}$ of $S$. rolfsii infested wheat grain with soil near plant base and covered with moist cotton [22]. Inoculation was done in the afternoon and cotton was kept moist by adding water as required. After 24 hrs later of inoculation, eight numbers of selected plant extracts with 20 percent of concentration drenched near the collar region @ $50 \mathrm{ml} / \mathrm{plants}$. Fifteen inoculated pot remained untreated as control. In the case of controls, $50 \mathrm{~m} 1$ of sterilized water was used to water the plants. After that disease incidence was recorded at 7 days interval up to 30 days of inoculation. Percent disease incidence was calculated by using the following formula.

$$
\text { Percent Disease Incidence }=\frac{\text { Number of plants showing wilting symptom }}{\text { Total number of plants }} \times 100
$$

\section{Results and Discussions}

Efficacy of medicinal plant extracts against Sclerotium rolfsii under in vitro Efficacy of eight medicinal plant extracts were tested at three different concentrations each by following poisoned food technique and the results of mycelial growth of Sclerotium rolfsii and percent inhabitation of mycelial growth has been presented in [Table-2]. The results revealed that in all the cases, significant differences were recorded in between untreated control and treatments. At $5 \%$ of concentration of phytoextracts, among all eight medicinal plant extracts, the Allium sativum showed maximum inhibition (35.31\%) of mycelia growth followed by Azadirachta indica (31.67\%), Zingiber officinale (29.39\%), Andrographis paniculata (25.11\%), Catharanthus roseus (16.58 \%), Allium cepa $(12.08 \%)$ and Curcuma longa (12.03 \%) respectively and the least inhibition of 10.67 percent was recorded in Ocimum sanctum. At $10 \%$ of concentration, among the eight medicinal plant extracts, the Allium sativum showed maximum inhibition (68.50\%) of mycelia growth followed by Azadirachta indica (65.61\%), Zingiber officinale (59.72\%), Andrographis paniculata (49.42\%), Catharanthus roseus (48.44\%), Curcuma longa (42.28\%) and Allium cepa (35.64\%) respectively and the least inhibition of 30.69 percent was recorded in Ocimum sanctum. At 20 $\%$ of phytoextract's concentration, among the eight medicinal plant extracts, the Allium sativum showed maximum inhibition ( $84.89 \%$ ) of mycelia growth followed by Azadirachta indica (80.86\%), Zingiber officinale (76.94\%), Andrographis paniculata (71.17\%), Catharanthus roseus (69.06\%), Allium cepa $(60.44 \%)$ and Curcuma longa ( $55.69 \%$ ) respectively and the least inhibition of 53.47 percent was recorded in Ocimum sanctum. The presents study revealed that Allium sativum showed maximum efficacy against Sclerotium rolfsii at different concentration in respect of all other treatments. The present results are in conformity with earlier workers. Antifungal properties of Allium sativum are well known, especially against human pathogens and against plant pathogens. It contains different antimicrobial components like allicin, E-and Z-ajoene, iso-E-10devinylajoene, and so forth, which are effective against bacteria, yeasts and phytopathogenic fungi $[23,24]$. Garlic contains some sulphur containing compounds such as allicin, ajoene, diallysulphide, dithin, sallulcysteine $[25,26]$. These compounds showed better antifungal activity than both antibiotics streptomycin and ampicillin [27]. 
Mahato A., Biswas M.K. and Patra S.

Table-2 Efficacy of medicinal plant extracts on mycelial growth of $S$. rolfsii under in vitro

\begin{tabular}{|c|c|c|c|c|c|c|c|}
\hline \multirow[t]{2}{*}{ SN } & \multirow[t]{2}{*}{ Medicinal plant } & \multicolumn{3}{|c|}{$\begin{array}{l}\text { Mean radial growth } \\
\text { of the fungus (mm) }\end{array}$} & \multicolumn{3}{|c|}{ Mycelial growth inhibition (\%) } \\
\hline & & $5 \%$ & $10 \%$ & $20 \%$ & $5 \%$ & $10 \%$ & $20 \%$ \\
\hline 1 & Kalmegh (Andrographis paniculata) & 67.40 & 45.53 & 25.95 & $25.11(30.05)$ & $49.42(44.67)$ & $71.17(57.54)$ \\
\hline 2 & Ginger (Zingiber officinale) & 63.55 & 36.25 & 20.75 & $29.39(32.82)$ & $59.72(50.61)$ & $76.94(61.32)$ \\
\hline 3 & Neem (Azadirachta indica) & 61.50 & 30.95 & 17.23 & $31.67(34.24)$ & $65.61(54.10)$ & $80.86(64.08)$ \\
\hline 4 & Garlic (Allium. sativum) & 58.23 & 28.35 & 13.60 & $35.31(36.45)$ & $68.50(55.87)$ & $84.89(67.13)$ \\
\hline 5 & Turmeric (Curcuma. longa) & 79.18 & 51.95 & 39.88 & $12.03(20.26)$ & $42.28(40.55)$ & $55.69(48.27)$ \\
\hline 6 & Periwinkle (Catharanthus roseus) & 75.08 & 46.40 & 27.85 & $16.58(24.02)$ & $48.44(44.11)$ & $69.06(56.20)$ \\
\hline 7 & Tulsi (Ocimum sanctum) & 80.40 & 62.38 & 41.88 & $10.67(19.00)$ & $30.69(33.63)$ & $53.47(46.99)$ \\
\hline 8 & Onion (Allium cepa) & 79.13 & 57.93 & 35.60 & $12.08(20.30)$ & $35.64(36.65)$ & $60.44(51.03)$ \\
\hline 9 & Control & 90.00 & 90.00 & 90.00 & $0.00(0.00)$ & $0.00(0.00)$ & $0.00(0.00)$ \\
\hline & $\mathrm{SEM} \pm$ & 0.84 & 0.92 & 0.83 & 0.69 & 0.61 & 0.60 \\
\hline & CD at $5 \%$ & 2.45 & 2.66 & 2.42 & 2.02 & 1.76 & 1.74 \\
\hline & CV & 2.33 & 3.67 & 4.81 & 5.77 & 3.04 & 2.39 \\
\hline
\end{tabular}

Note: Figures in parenthesis are angular transformed values

Table 3- Efficacy of medicinal plant extracts on collar rot disease of tomato caused by S. rolfsii under in vivo

\begin{tabular}{|c|c|c|c|c|c|c|}
\hline \multirow[t]{2}{*}{ Treatments } & \multicolumn{2}{|c|}{ 2014-15 } & \multicolumn{2}{|c|}{$2015-16$} & \multicolumn{2}{|c|}{ Pooled } \\
\hline & $\begin{array}{c}\text { Disease Incidence } \\
(\%)\end{array}$ & $\begin{array}{c}\text { Disease Control } \\
(\%)\end{array}$ & $\begin{array}{c}\text { Disease } \\
\text { Incidence (\%) }\end{array}$ & $\begin{array}{c}\text { Disease Control } \\
(\%)\end{array}$ & $\begin{array}{c}\text { Disease Incidence } \\
(\%)\end{array}$ & $\begin{array}{c}\text { Disease Control } \\
(\%)\end{array}$ \\
\hline Kalmegh (Andrographis paniculata ) & $45.67(42.51)^{*}$ & $51.62(45.93)$ & $47.00(43.28)$ & $49.45(44.69)$ & 46.33(42.89) & $50.54(45.31)$ \\
\hline Ginger (Zingiber officinale) & $38.89(38.54)$ & $58.83(50.12)$ & $38.89(38.58)$ & $58.23(49.74)$ & $38.89(38.57)$ & $58.53(49.92)$ \\
\hline Neem (Azadirachta indica) & $33.33(35.24)$ & $64.69(53.57)$ & $30.56(33.48)$ & $67.26(55.15)$ & $31.95(34.38)$ & $65.97(54.35)$ \\
\hline Garlic (Allium sativum) & $37.50(37.74)$ & $60.34(50.98)$ & $34.72(36.10)$ & $62.65(52.34)$ & $36.11(36.93)$ & $61.50(51.65)$ \\
\hline Turmeric (Curcuma longa) & $52.78(46.60)$ & $44.20(41.66)$ & $51.39(45.80)$ & $44.67(41.91)$ & $52.08(46.20)$ & $44.44(41.78)$ \\
\hline Periwinkle (Catharanthus roseus) & $54.17(47.40)$ & $42.62(40.74)$ & $54.17(47.41)$ & $41.63(40.12)$ & $54.17(47.40)$ & $42.13(40.45)$ \\
\hline Tulsi (Ocimum sanctum) & $66.67(54.76)$ & $29.38(32.78)$ & $69.44(56.45)$ & $25.30(30.14)$ & $68.06(55.59)$ & $27.34(31.51)$ \\
\hline Onion (Allium cepa) & $62.50(52.26)$ & $33.73(35.45)$ & $61.11(51.46)$ & $34.32(35.79)$ & $61.81(51.84)$ & $34.02(35.67)$ \\
\hline Control & $94.44(76.55)$ & $0.00(0.00)$ & $93.06(74.89)$ & $0.00(0.00)$ & $93.75(75.52)$ & $0.00(0.00)$ \\
\hline $\mathrm{SEM} \pm$ & 1.64 & 1.64 & 1.75 & 1.96 & 1.30 & 1.39 \\
\hline CD at $5 \%$ & 4.88 & 4.88 & 5.21 & 5.83 & 3.86 & 4.13 \\
\hline CV & 5.94 & 7.29 & 6.39 & 8.74 & 4.71 & 6.17 \\
\hline
\end{tabular}

*Note: Data parenthesis is angular transform value

Durairaj, et al., [28] showed that allicin exhibits its antimicrobial activity mainly by immediate and total inhibition of RNA synthesis, also, Garlic extract is considered to inhibit cell wall synthesis because it inhibits transpeptidation enzymes involved in crosslinking. Kurucheve and Padmavathi, [29] found that Allium sativum (garlic) bulb recorded the minimum mycelial growth (176 mg). Gupta, et al., [30] evaluated the efficacy of extracts of garlic, neem (Azadirachta indica), ginger, marigold (Tagetes erecta), lantana (Lantana camara), madar (Calotropis gigantea), ashok (Polyalthia longifolia), parthenium (Parthenium hysterophorus), clerodendron (Clerodendrum inerme), eucalyptus (Eucalyptus globulus), onion, mehandi (Lawsonia alba), bhang (Cannabis sativa), tulsi (Ocimum sanctum), karanj (Pongamia pinnata) and sadabahar (Vinca rosea), each at 5 and $10 \%$, in vitro against $S$. rolfsii, causing collar rot of chickpea and reported percentage inhibition at $42 \mathrm{~h}$ on radial growth at $10 \%$ was $100 \%$ in garlic, followed by neem $(97.0 \%)$, ginger $(95.8 \%)$, marigold $(95.6 \%)$, lantana $(87.1 \%)$, madar $(79.9 \%)$, ashok $(77.4 \%)$, parthenium $(70.8 \%)$, clerodendron $(66.3 \%)$, eucalyptus $(61.9 \%)$ and onion $(55.9 \%)$.

\section{Efficacy of medicinal plant extracts against collar rot of tomato under in vivo} To know the efficacy of medicinal plant extract on collar rot disease incidence, pot experiment was carried out in protected condition by artificial soil inoculation methods in two years 2014-15 and 2015-16 and the data were recorded in respect of disease incidence. The outcome of that experiment has been presented in [Table-3]. All the treatments showed significant reduction of disease incidence in respect of untreated control in both year of evaluation as well as also in pooled analysis of two year data. In first year Azadirachta indica showed best effectiveness against collar rot disease by reducing $64.69 \%$ incidence which followed by Allium sativum (60.34 \%), Zingiber officinale (58.83\%), Andrographis paniculata (51.62\%), Curcuma longa (44.20\%) Catharanthus roseus (42.62\%) and Allium cepa (33.73\%) in respect of control whereas the Ocimum sanctum showed least reduction of disease incidence (29.38\%). In second year same results noticed, Azadirachta indica again showed best effectiveness against collar rot disease by reducing 67.26 percent of disease incidence which followed by Allium sativum (62.65\%), Zingiber officinale (58.23\%), Andrographis paniculata (49.45\%), Curcuma longa (44.67 \%) Catharanthus roseus (41.63\%) and Allium cepa $(34.32 \%)$ in respect of control whereas the Ocimum sanctum showed least reduction of disease incidence $(25.30 \%)$. Pooled analysis of the data spanning over two years i.e. 2014-15 and 2015-16 [Table-3] indicated that nearly all medicinal plants extracts proved effective in reduction of disease incidence. From the pooled data, Azadirachta indica was found to be the best treatment for reducing the disease (65.97\%) followed by Allium sativum (61.50\%), Zingiber officinale (58.53\%), Andrographis paniculata (50.54\%), Curcuma longa (44.44\%) Catharanthus roseus (42.13\%) Allium cepa $(34.02 \%)$ and Ocimum sanctum $(27.34 \%)$ in respect to control. All the treatments were found to control collar rot disease significantly. Botanicals control is very important aspects to minimize the cost of cultivation and also to avoid the health hazards. Some of the botanicals were tested for their efficacy against $S$. rolfsii. This in turn may indicate about the use of such botanicals in plant disease control. The results of the present studies are in confirmatory to Okereke and Wokocha, [31] who reported that, the inhibition of damping-off disease of tomato incited by $S$. rolfsii was highest with soil drenching with neem seed $(62.4 \%)$ followed by ginger (57.4\%). A Similar experiment was carried out by Gupta, et al., [30] with extracts of garlic, neem (Azadirachta indica), ginger, marigold (Tagetes erecta), lantana (Lantana camara), madar (Calotropis gigantea), ashok (Polyalthia longifolia), parthenium (Parthenium hysterophorus), clerodendron (Clerodendrum inerme), eucalyptus (Eucalyptus globulus), onion, mehandi (Lawsonia alba [Lawsonia inermis]), bhang (Cannabis sativa), tulsi (Ocimum sanctum [0. tenuiflorum]), karanj (Pongamia pinnata) and 
sadabahar (Vinca rosea [Catharanthus roseus]), each at 5 and 10\%, were tested in vitro and in vivo against $S$. rolfsii, causing collar rot of chickpea and he reported that the maximum disease control in garlic $(76.7 \%)$, followed by neem $(75.7 \%)$, ginger $(74.4 \%)$, marigold $(71.7 \%)$, lantana $(68.3 \%)$, madar $(67.9 \%)$, ashok (66.0\%), parthenium (65.0\%), clerodendron (65.0\%) and tulsi $(52.3 \%)$. Islam and Faruq, [32] studied garlic clove, allamonda leaf, ginger rhizome, neem leaf, kalijira seed, turmeric rhizome, bel leaf, katamehedi leaf and onion bulb were effective against damping-off of tomato but neem leaf extract was most efficient than other extract.

\section{Conclusion}

The results obtained in this experimental study revealed that the under in vitro phytoextracts of Allium sativum showed maximum inhibition of mycelial growth whereas under in vivo, soil drenching of aqueous extract of Azadirachta indica with $20 \%$ of concentration, effectively reduced the disease incidence of collar rot disease. Based on the investigation, it may conclude that soil drenching of phytoextracts such as Azadirachta indica and Allium sativum should be use for sustainable management of collar rot disease of tomato. Though, further research has also been undertaken to find out the mechanism of action and efficacy of these phytoextracts application at field level.

\section{Application of research:}

The findings of this research will be applicable for preparation of botanical pesticides at farmer's as well as industrial level to sustainable manage the collar rots disease of tomato and it will be play important role in organic farming

\section{Research Category: Medicinal Plant Extracts}

Abbreviations: PDA - Potato Dextrose Agar, RNA- Ribo Nucleic Acid, W/VWeight/Volume.

Acknowledgement / Funding: Author thankful to Visva-Bharati, Institute of Agriculture, Sriniketan, West Bengal, 731236, India

\section{*Research Guide: Dr Mohan Kumar Biswas}

Department of Plant Protection, Institute of Agriculture, Visva-Bharati, Sriniketan, West Bengal, 731236, India

Research project name or number: PhD Thesis

\section{Author Contributions: All author equally contributed}

Author statement: All authors read, reviewed, agree and approved the final manuscript

\section{Conflict of Interest: None declared}

Ethical approval: This article does not contain any studies with human participants or animals performed by any of the authors.

\section{References}

[1] Begum H. A., Akhter M. N. and Salam M. A. (2011) Int. J. Sustain. Crop Prod., 6(2), 29-35.

[2] Cooper W.E. (1961) Phytopathology 51, 113-116.

[3] Ahmed F. (1980) M.S. thesis, Dept. of Plant Pathology Department, Bangladesh Agricultural University (BAU), Mymensingh.

[4] Wink M. (1993) In: Phytochemistry and Agric. Clarendon, Oxford, UK. 34, 171-213.

[5] Kandasamy D., Keseran R, Ramasamy K. and Rrasad N. N. (1974) Indian J. Microbiol., 14, 25-30.

[6] Hale C. N. and Mathers D. J. (1977) J. Agric. Res., 20,69-73.

[7] Rahber-Bhatti M. H. (1986) Pak J. Bot., 18, 329-333.

[8] Kalo F. and Taniguchi T. (1987) Ann. of Phytopath. Sec. Japan, 53, 159-167.
[9] Seshakiran K., Lingaraju S. and Adiver S. S. (2006) J. Mycol. PI. Path., 36, 77-79.

[10] Sheoraj S., Prajapathi, R. K., Srivastava S. S. L., Pandey R. K. and Gupta P. K. (2007) Ind. Phytopath., 60, 499-501.

[11] Deepak K. S. and Heera L. Y. (2008) Ind. Phytopath., 61, 99-102.

[12] Devlin J. F. and Zettel T. (1999) Eco-agriculture: Initiatives in Eastern and Southern Africa, 6(2), 150-152.

[13] Grange N. and Ahmed S. (1988) Handbook of Plants with Pest Control Properties, 7(5), 75-78.

[14] Roy B., Amin R., Uddin M.N., Islam A.T.M.S., Islam M. J. and Halder, B. C. (2005) Journal of Biological Sciences, 5(2), 201-204.

[15] Rangaswami G. and Mahadevan A. (1999) Diseases of crop plants in India. Prentice Hall of India Pvt. Ltd., New Delhi, 6079.

[16] Tuite J. (1996) Plant Pathological Methods. Fungi and Bacteria Burgess Pub. Co. Minneapolis, Minn. USA, 293.

[17] Barnett H.H. and Hunter B.B. (1972) Illustrated genera of Imperfect fungi. Burgess Publishing Company, Minnesota, 241.

[18] Kamlesh M. and Gujar R.S. (2002) Annual Plant Protection Sciences, 10(2), 319-322.

[19] Prasad S.M. and Barnwal M.K. (1994) Indian Phytopathol., 57, 110 111.

[20] Nene Y.L. and Thaplial P.N. (1982) Fungicides in Plant Disease Control. Oxford and IBH Publishing House, New Delhi, p.163.

[21] Vincent J. M. (1927) Nature, 159, 850.

[22] Babar H. M. (1999) Ph. D. thesis, Dept. Plant Pathology, Bangladesh Agricultural University, Mymensingh, Bangladesh, 153.

[23] Prithiviraj B., Singh U.P., Singh K.P. and Plank-Schumacher K. (1998) Journal of Plant Diseases and Protection, 105, 274-278.

[24] Yoshida H., Katsuzaki H., Ohta R., Ishikawa K., Fukuda H., Fujino T. and Suzuki A. (1999) Bioscience Biotechnology \& Biochemistry, 63 588-590.

[25] Cavallito C. J., Bailey J. H. and Allicin B. J. (1945) J. Am. Chem. Soc. 67, 1032-3.

[26] Ross Z. M., Maslin D. J. and Hill D. J. (2000) FEMS Microbiol. Rev. 12:137.

[27] Ilic D., Nikolic V., Ciric A., Sokovic M. and Stanojkovic T. (2012) J. Med. Plants Res, 6, 59-65.

[28] Durairaj S., Srinivasan S. and Lakshmanaperumalsamy P. (2009) Electron. J. Biol., 5,5-10.

[29] Kurucheve V. and Padmavathi R. (1997) Indian Pathology, 50(4), 529-530.

[30] Gupta R.P., Singh S.K., Mishra R.S. and Gupta S. (2012) Annals of Plant Protection Sciences, 20(2), 486-487.

[31] Okereke V.C. and Wokocha R.C. (2006) Agricultural Journal, 1, 52-54.

[32] Islam M.T., Faruq A.N. (2012) World Applied Sciences Journal, 17(11), 1498-1503. 